\title{
PENANAMAN NILAI-NILAI PENDIDIKAN KARAKTER MELALUI MATA PELAJARAN SOSIOLOGI
}

\author{
Noviani Achmad Putri ${ }^{凶}$ \\ Pascasarjana Universitas Negeri Semarang, Indonesia
}

\section{Info Artikel}

Sejarah Artikel:

Diterima Juni 2011

Disetujui Juli 2011

Dipublikasikan September 2011

Keywords:

character education; sociology;

senior high school.

\begin{abstract}
Abstrak
Pembangunan fisik perlu diimbangi dengan pembangunan moral. Salah satu cara pembangunan moral terhadap generasi muda adalah melalui pendidikan karakter yang dilaksanakan di lembaga Sekolah Menengah Atas. Tujuan penelitian ini adalah mengungkapkan model penanaman nilai-nilai pendidikan karakter melalui mata pelajaran Sosiologi. Penelitian dilaksanakan di SMA Negeri 5 Semarang. Hasil penelittian menunjukkan bahwa pendidikan karakter di SMA Negeri 5 Semarang dilaksanakan dengan cara diintegrasikan ke semua mata pelajaran yang ada. Penanaman nilai-nilai pendidikan karakter melalui mata pelajaran Sosiologi dapat ditinjau dari beberapa aspek, di antaranya: materi Sosiologi yang telah dianalisis nilai-nilai karakternya, RPP dan Silabus Sosiologi yang berkarakter, metode penanaman oleh guru, media pembelajaran berbasis karakter dan evaluasi penanaman nilai-nilai pendidikan karakter. Pengembangan dan penanaman nilai-nilai pendidikan karakter di SMA Negeri 5 Semarang juga dilakukan melalui penyediaan fasilitas seperti tempat ibadah, laboratorium bahasa dan budaya serta Pusat Sumber Belajar yang baik serta ditunjang dengan berbagai program sekolah mulai dari ekstra kurikuler, pengembangan budaya sekolah, wawasan wiyata mandala dan tentunya ditunjang dengan visi dan misi sekolah yang ada.
\end{abstract}

\begin{abstract}
Physical development needs to be balanced with moral development. One way of moral development in young people is through character education held in institutions of senior high school. The purpose of this study is to explore the experience of SMAN 5 Semarang in habituating character education through Sociology. The research results show that character education in SMA Negeri 5 Semarang is implemented integratedly into the existing subjects. The investment of character education values through sociology courses can be viewed from several aspects, such as character values, character-based lesson plan and syllabus, character building by teachers, character-based learning media and evaluation of the investment of character education values. Development and cultivation of character education values in SMA Negeri 5 Semarang is also done through the provision of facilities such as places of worship, cultural and language labs and good Learning Resource Center, accompanied by a variety of programs ranging from extra-curricular activity, school culture development, wiyata mandala insight and of course supported by the vision and mission of the school.
\end{abstract}

(C) 2011 Universitas Negeri Semarang 


\section{PENDAHULUAN}

Pembangunan terus dilaksanakan di segala bidang kehidupan baik oleh pemerintah pusat, kota maupun daerah dengan tujuan untuk mensejahterakan masyarakat. Pembangunan mencakup pada aspek fisik maupun non-fisik. Pembangunan pada aspek fisik dapat dilihat dari bangunan gedunggedung, sarana dan prasarana yang semakin banyak berada di kota maupun daerah. Pembangunan fisik kurang berguna secara maksimal apabila tidak diimbangi dengan pembangunan pada sumber daya manusianya. Manusia adalah pelaku utama dalam pembangunan sehingga diperlukan adanya pembangunan pada sumber daya manusia. Sumber daya manusia tidak hanya kecerdasannya saja melainkan juga pada aspek moralnya. Moral manusia sangat penting untuk proses pembangunan, karena tanpa moral yang baik maka pembangunan secara fisik pun akan sia-sia.

Selama ini pembangunan yang dilakukan pemerintah baik pusat, kota atau daerah sebagian besar ditekankan pada aspek fisik, sehingga yang terjadi tujuan pembangunan tidak dapat tercapai secara optimal. Pembangunan fisik yang kurang diimbangi dengan pembangunan karakter maka banyaknya masalah sosial yang masih terjadi di masyarakat, misalnya terjadinya konflik sosial, pergaulan generasi muda yang tidak terkendali, perkelahian dan tawuran antar pelajar, menurunnya nilai-nilai nasionalisme dan patriotisme serta pengagungan terhadap nilai budaya asing, sehingga menyebabkan nilai-nilai lokal dan nasional menjadi terabaikan. Bahkan terkadang pembangunan fisik yang sudah dilaksanakan sedemikian rupa dirusak sendiri oleh masyarakat dalam berbagai peristiwa seperti demonstrasi, tawuran dan lain sebaginya. Kondisi semacam itu menandakan bahwa masyarakat telah mengalami degradasi moral yang sangat memprihatinkan. Adanya degradasi moral mendesak pemerintah perlu melakukan upaya untuk membentuk masyarakat agar mempunyai karakter yang baik sehigga moral yang dimiliki masyarakat pun juga baik.

Strategi yang tepat dalam membentuk masyarakat yang berkarakter dan bermoral salah satunya melalui pendidikan. Pendidikan mempunyai peran untuk membangun masyarakat yang lebih dewasa (memecahkan konflik atau perbedaan pendapat dengan cara damai, mau belajar mengatur diri sendiri). Pendidikan sebagai sarana untuk membangun masyarakat dan bukan untuk saling menutup diri, saling mengasingkan diri, bukan saling untuk mencerca serta belajar untuk menemukan solusi bersama ditengah-tengah perbedaan. Pendidikan merupakan proses yang paling bertanggung jawab dalam melahirkan warga negara Indonesia yang memiliki karakter kuat sebagai modal dalam membangun peradaban tinggi dan unggul. Standar Nasional Pendidikan ketika dalam penyusunan juga disebutkan dalam salah satu fungsinya adalah bertujuan untuk menjamin mutu pendidikan nasional dalam rangka mencerdaskan kehidupan bangsa dan membentuk watak serta peradaban bangsa yang bermartabat, jelas bahwa arah dari tujuan penyelenggaraan pendidikan sangat luhur dalam keinginannya mewujudkan manusia yang bermartabat yang memiliki karakter yang mulia.

Tantangan pendidikan dewasa ini untuk menghasilkan SDM yang berkualitas dan tangguh semakin berat. Pendidikan tidak cukup hanya berhenti pada memberikan pengetahuan yang paling mutakhir, namun juga harus mampu membentuk dan membangun sistem keyakinan dan karakter kuat setiap peserta didik sehingga mampu mengembangkan potensi diri dan menemukan tujuan hidupnya. Pendidikan di sekolah tidak lagi cukup hanya dengan mengajar peserta didik membaca, menulis, dan berhitung, kemudian lulus ujian dan nantinya mendapatkan pekerjaan yang baik. Sekolah harus mampu mendidik peserta didik untuk mampu memutuskan apa yang benar dan salah, serta sekolah juga perlu membantu orang tua untuk menemukan tujuan hidup peserta didik.

Di tengah-tengah proses pembangunan, perkembangan dunia yang begitu cepat dan semakin kompleks serta canggih, prinsip-prinsip pendidikan untuk membangun etika, nilai dan karakter peserta didik tetap harus dipegang akan tetapi, perlu dilaku- 
kan dengan cara yang berbeda atau kreatif sehingga mampu mengimbangi perubahan kehidupan. Guru harus memiliki komitmen yang kuat dalam melaksanakan pendidikan secara holistik yang berpusat pada potensi dan kebutuhan peserta didik. Pendidik juga harus mampu menyiapkan peserta didik untuk bisa menangkap peluang dan kemajuan dunia dengan perkembangan ilmu dan teknologi akan tetapi di sisi lain, pendidik juga harus mampu membukakan mata hati peserta didik untuk mampu melihat masalahmasalah dalam proses pembangunan bangsa ini.

Peserta didik harus diarahkan untuk mampu mengembangkan dirinya, tetapi ia juga harus diajarkan untuk memiliki beban atau panggilan hidup untuk menjadi bagian dari pemecahan persoalan-persoalan yang dihadapi bangsa dan dunia. Pendidikan karakter sangat penting, mengingat bangsa ini mengalami banyak persoalan bangsa dan keterpurukan karena minimnya insan-insan cendekia yang cerdas dan berkarakter kuat. Kebanggaan terhadap institusi pendidikan mulai dari dasar sampai perguruan tinggi telah menghasilkan insan-insan cendikia yang cerdas dan unggul tidak diragukan lagi, namun demikian, hal ini juga perlu diikuti oleh pembentukan karakter dalam dunia pendidikan seperti yang telah dipelopori oleh tokoh pendidikan, Ki Hajar Dewantoro melalui filsafatnya ing ngarso sung tulodho, ing madyo mangan karso, tutwuri handayani (di depan memberi contoh, di tengah ikut berkarya, di belakang tutur mendukung). Pembentukan karakter tersebut harus dilakukan dengan komitmen dan kerja keras bersama antara peserta didik, guru, dosen dan semua stake holders pendidikan untuk mencerdaskan dan mewujudkan cita-cita bangsa dan negara Indonesia tercinta.

Pentingnya karakter untuk membangun SDM yang berkualitas, maka pendidikan karakter perlu dilakukan dengan tepat, sehingga pembentukan karakter merupakan sesuatu yang tidak dapat dipisahkan dari kehidupan. Pendidikan karakter juga harus menyertai semua aspek kehidupan termasuk dilembaga pendidikan. Idealnya pembentukan atau pendidikan karakter diintegrasikan keseluruh aspek kehidupan sekolah. Lembaga pendidikan, khususnya sekolah dipandang sebagai tempat yang strategis untuk membentuk karakter siswa, serta dimaksudkan agar peserta didik dalam segala ucapan, sikap, dan perilakunya, mencerminkan karakter yang baik dan kuat.

Pendidikan karakter yang secara sistematis diterapkan pada salah satu lembaga sekolah formal yaitu Sekolah Menengah Atas (SMA) merupakan suatu kemajuan yang cukup baik. Para peserta didik memperoleh perilaku dan kebiasaan positif yang mampu meningkatkan rasa percaya diri mereka. Pendidikan karakter yang diterapkan pada lembaga pendidikan formal juga bisa menjadi salah satu sarana pembudayaan dan pemanusiaan. Semua tujuan yang diharapkan pada pendidikan karakter dapat tercapai salah satunya melalui mata pelajaran yang ada di sekolah. Mata pelajaran tersebut yang mempunyai peran dalam pengembangan nilai-nilai pendidikan karakter tersebut salah satunya adalah mata pelajaran Sosiologi.

Mata pelajaran Sosiologi sebagai salah satu penanaman nilai-nilai pendidikan karakter, salah satunya akan tampak pada lembaga sekolah formal pada jenjang Sekolah Menengah Atas (SMA). Pada jenjang SMA perlu diadakan kajian terhadap bagaimana pelakasanaan pendidikan karakter yang berlangsung sebagai upaya mencetak kader bangsa yang intelektual, bermoral dan berkarakter. Salah satu SMA yang akan dikaji atau diteliti tersebut adalah SMA Negeri 5 Semarang. Penelitian akan dilakukan di SMA Negeri 5 Semarang.

Secara geografis SMA Negeri 5 Semarang ini berada di pusat kota Semarang. SMA Negeri 5 Semarang merupakan salah satu sekolah yang dapat dijadikan teladan bagi sekolah lain baik di dalam kota maupun luar kota. Berbagai prestasi telah diraih baik dalam bidang akademik maupun non akademik. Prestasi tersebut tidak akan ada artinya apabila tidak diiringi dengan moral yang baik terhadap para civitas akademik SMA Negeri 5 Semarang itu sendiri. Kondisi tersebut merupakan salah satu tantangan bagi pihak sekolah bagaimana dapat tetap ber- 
prestasi namun, masih dapat juga mengelola dan membina karakter, moral dan tingkah laku yang luhur pada semua civitas akademik SMA Negeri 5 Semarang khusunya para peserta didik.

Fokus penelitian ini pada kelas X, karena di kelas $\mathrm{X}$ inilah semua siswa mendapatkan beberapa mata pelajaran Sosiologi yang dapat menjadi salah satu perantara penanaman nilai-nilai pendidikan karakter secara dini pada jenjang sekolah menengah. Mata pelajaran Sosiologi yang ada juga diharapkan dapat menjadi dasar sebagai pembentuk karakter peserta didik agar dalam segala ucapan, sikap, dan perilakunya, dapat mencerminkan karakter yang baik dan kuat. Bertolak dari latar belakang di atas, muncul pertanyaan dapatkah mata pelajaran Sosiologi sebagai salah satu cara dalam penanaman nilai-nilai pendidikan karakter sehingga peserta didik nempunyai perilaku yang baik dalam kehidupan sehari-harinya.

Penelitian Raharjo (2010) tentang Pendidikan Karakter Sebagai Upaya Menciptakan Akhlak Mulia, menyimpulkan bahwa Pendidikan karakter dapat mempengaruhi akhlak mulia peserta didik. Tujuan membangun karakter dan watak bangsa melalui pendidikan mutlak diperlukan, bahkan tidak bisa ditunda. Pendidikan yang mengembangkan karakter adalah bentuk pendidikan yang bisa membantu mengembangkan sikap etika, moral dan tanggung jawab, memberikan kasih sayang kepada peserta didik dengan menunjukkan dan mengajarkan karakter yang bagus. Karakter yang harus ditanamkan kepada peserta didik diantaranya adalah; cinta kepada Allah dan alam semesta berserta isinya, tanggung jawab, disiplin dan mandiri, jujur, hormat dan santun, kasih sayang, peduli dan kerja sama, percaya diri dan kreatif, kerja keras dan patang menyerah, keadilan dan kepemimpinan, baik dan rendah hati, toleransi, cinta damai dan persatuan.

Penelitian Akrab (2010) dengan judul Model Pembelajaran Nilai dan Karakter Berbasis Nilai-nilai Kehidupan di Sekolah Dasar mengungkapkan bahwa SD di Jawa Timur sudah menjalankan pendidikan nilai dan karakter secara terintegrasi pada berbagai mata pelajaran dan praktik kehidupan di sekolah.
Pelaksanaan pendidikan nilai dan karakter tersebut ternyata belum optimal karena pelaksanaanya belum dilakukan secara sistematik, terprogram secara khusus, dan belum maksimal sesuai prinsip-prinsip pendidikan nilai dan karakter. Nilai-nilai yang mendominasi dalam praktik pendidikan nilai dan karakter di SD Jawa Timur adalah nilai tanggung jawab, kedisiplinan, dan kepatuhan pada peraturan. Nilai-nilai yang lain belum dikembangkan secara optimal. Model pembelajaran nilai dan karaker yang di tawarkan mencakup aspek grand desain, yaitu dengan perumusan kembali visi, misi dan tujuan sekolah sehingga sesuai dengan pendidikan nilai dan karakter, penataan situasi fisik untuk pendidikan nilai dan karakter di SD, penataan kehidupan sosial untuk pendidikan nilai dan karakter, penyempurnaan tata tertib bagi siswa, guru, kepala, sekolah, orang tua siswa dan tenaga administrasi untuk pembelajaran nilai dan karakter, dan program-program kegiatan untuk pembelajaran nilai dan karakter.

Dalam pendidikan tinggi, khususnya di Jurusan Teknik Industri Universitas Kristen Petra, Chrisiana (2005) memberikan pendapat bahwa penting bagi perguruan tinggi untuk tidak hanya memperhatikan kebutuhan kompetensi akademis mahasiswa, tapi juga pembinaan karakternya agar lulusan menjadi lulusan yang siap secara akademis dan berkarakter baik. Keinginan jurusan TI UKP untuk membina karakter mahasiswa telah dituangkan ke dalam rencana strategisnya dan perancangan program yang sistematis dan terintegrasi sudah mulai dilakukan. Sebagai pilot project, dilakukan program live in dan pekan kepedulian. Hasil dari program ini memang tidak dapat langsung merubah karakter mahasiswa, namun telah memberikan warna positif dalam suasana perkuliahan. Untuk ke depannya, perancangan pendidikan karakter harus terus dilakukan dengan komitmen yang tinggi dan dilakukan usaha perbaikan terus menerus.

Judiani (2010), dalam kajiannya menyatakan bahwa pendidikan di Indonesia selama ini masih mengedepankan aspek kognitif atau akademis, sedangkan aspek soft skills atau non akademis yang mendukung pen- 
didikan karakter belum banyak mendapat perhatian. Sehingga pelaksanaan pendidikan karakter ini menjadi hal yang sangat signiufikan untuk diimplementasikan. Pendidikan karakter juga berorientasi pada tujuan pendidikan yang mengarahkan pada kecerdasan mental, disamping pada pencapaian tujuan akademis semata. Khusus pada level pendidikan dasar, pendidikan karakter ini diintegrasikan dalam mata pelajaran yang sudah ada, seperti muatan lokal, pengembangan diri, dan budaya sekolah.

Handoyo dan Tijan (2010) dalam bukunya berjudul Model Pendidikan Karakter Bernasis Konservasi, Pengalaman Universitas Negeri Semarang, mengungkapkan bahwa pengembangan pendidikan karakter yang dilakukan di Unnes terintegrasi dalam kegiatan pembelajaran akademik dan kegiatan kemahasiswaan. Pembelajaran akademik yang dilaksanakan dengan berbagai metode merupakan salah satu cara pelaksanaan pendidikan karakter di Unnes. Pelaksanaan pendidikan karakter tidak hanya mencakup aspek akademik saja tetapi juga mencakup aspek luar akademik yaitu melalui bidang kemahasiswaan.

Penelitian ini menggunakan teori dari perkembangan belajar menurut Sosiologi. Tokoh pedagog Sosiologi adalah Baldwin (dalam Fudyartanta, 2010:65-66) yang konsepsinya cukup mempunyai pengaruh besar. Baldwin mempunyai pengaruh terutama pada hipotesisnya mengenai reaksi sirkuler. Baldwin menerangkan perkembangan anak sebagai proses sosialisasi dalam bentuk meniru atau imitasi yang berlangsung secara adaptasi dan seleksi.

Adaptasi atau penyesuaian dan seleksi tadi berlangsung atas dasar hukum efek dari Thorndike (teori belajar koneksionisme). Tingkah laku pribadi diterangkan sebagai peniruan, kebiasaan adalah peniruan pada tingkah laku sendiri sedangkan adaptasi adalah peniruan terhadap orang lain. Tingkah laku mempunyai efek (hasil) maka tingkah laku menjadi dipertahankan, dan seterusnya karena efek dapat meningkatkan prestasi kegiatan. Proses yang demikian maka terciptalah inisiatif dan daya cipta, sehingga manusia dapat menemukan alat-alat, akibat meniru diri sendiri. Proses itu pula, juga dapat dikatakan bahwa akunya anak merupakan pemancaran akunya orang lain yang menjadi objek penirunya. Baldwin juga membedakan dua macam peniruan, yaitu peniruan naif (wantah, apa adanya), disebut nondeliberate imitation dan deliberate imitation, suatu peniruan dengan pertimbangan. Proses peniruan tersebut dalam teori ini terjadi melalui tiga fase, diantaranya: (1) Fase proyektif, (2) Fase subjektif, (3) Fase objektif.

Nilai-nilai pendidikan karakter menurut Permendiknas No. 2 Tahun 2010 diantaranya: Religius, Jujur, Toleransi, Disiplin, Kerja Keras, Kreatif, Mandiri, Demokratis, Rasa Ingin Tahu, Semangat Kebangsaan, Cinta Tanah Air, Menghargai Prestasi, Bersahabat atau Komunikatif, Cinta Damai, Gemar Membaca, Peduli Lingkungan, Peduli Sosial, Tanggung-jawab. Nilai-nilai yang dapat dihayati dalam penelitian ini diantaranya: Komunikatif, Nasionalisme, Peduli Sosial, Religius, Toleransi, Disiplin, Demokratis, Rasa Ingin Tahu, Jujur, Santun, Tangguh, dan Tanggungjawab. Pendidikan karakter mempunyai tiga matra yang menjadi dasar tindakan penting seseorang dalam bertindak. Matra tersebut diantaranya individu, sosial dan moral (Albertus, 2010).

\section{METODE PENELITIAN}

Penelitian ini menggunakan metode penelitian kualitatif. Metode kualitatif ini digunakan sebagai prosedur penelitian yang menghasilkan data deskriptif berupa katakata tertulis atau lisan dari orang-orang dan perilaku yang dapat diamati. Data yang dihasilkan dalam penelitian ini adalah data yang berupa kata-kata dari para subjek dan informan baik dalam kata-kata tertulis ataupun lisan.

Penelitian ini menggunakan metode penelitian kualitatif karena dalam penelitian ini data yang diperoleh adalah datadata yang berupa data deskriptif yang tidak menggunakan data yang berupa angka untuk menerangkan hasil penelitian. Metode penelitian yang digunakan dalam penelitian ini disesuaikan dengan tujuan pokok penelitian yaitu untuk mendiskripsikan "Penanaman 
Nilai-Nilai Pendidikan Karakter Melalui Mata Pelajaran Sosiologi Kelas X Di SMA Negeri 5 Semarang Tahun Pelajaran 2010/ tahun 2011'.

\section{HASIL DAN PEMBAHASAN}

SMA Negeri 5 Semarang berada dalam posisi yang serba menguntungkan. Lokasinya strategis, berada di jantung Kota Semarang, sarana-prasarana ditata secara menarik dan cukup representatif untuk kegiatan proses pembelajaran. Sistem manajemen kependidikan digarap secara serius sehingga mampu meningkatkan etos kerja yang lebih peduli terhadap perkembangan peserta didik. Peserta didik yang berminat belajar di SMA Negeri 5 Semarang juga kategori bernilai baik. Inilah yang kemudian SMA Negeri 5 Semarang menjadi salah satu sekolah pilihan bagi calon peserta didik dan orang tua di antara sekian sekolah favorit di Semarang.

SMA Negeri 5 Semarang berlokasi di Jalan Pemuda 143 Semarang, kode pos 50132. Letaknya strategis karena terletak di pusat kota, yaitu di sekitar Tugu Muda Semarang sehingga mudah dijangkau oleh para peserta didik. SMA Negeri 5 Semarang mempunyai akreditasi sangat baik dalam kategori jenjang Sekolah Menengah Atas dengan status negeri di bawah Diknas.

Pelaksanaan pendidikan karakter di SMA Negeri 5 Semarang ini dispesifikan lagi kedalam penanaman nilai-nilai pendidikan karakter melalui mata pelajaran Sosiologi kelas X. Sosiologi yang diajarkan di setiap satuan pendidikan sangatlah tepat antara lain Sosiologi mengajarkan peserta didik, baik sebagai individu atau anggota kelompok mampu menempatkankan diri sesuai statusnya di dalam masyarakat. Pada saat sekarang ini konsep pendidikan karakter populer lagi didengungkan oleh bangsa Indonesia, sebagai jalan untuk memperbaiki moral bangsa. Berdasarkan prinsip pendidikan karakter di atas, mata pelajaran Sosiologi mempunyai andil dalam penanaman nilai-nilai pendidikan karakter. Penanaman tersebut dapat melalui beberapa cara yang digunakan oleh pendidik dalam menyampaikan pemahaman dan pe- laksanaan langsung terkait dengan pendidikan karakter itu sendiri, di antaranya materi, silabus, media, pedagogi dan evaluasi.

Pertama melalui materi. Penanaman nilai-nilai pendidikan karakter melalui mata pelajaran Sosiologi salah satunya melalui materi mata pelajaran Sosiologi itu sendiri. Materi Sosiologi mempunyai karakteristik berdasarkan BNSP (2006), yaitu materi Sosiologi mempelajari perilaku dan interaksi perilaku dan interaksi kelompok, menelusuri asal-usul pertumbuhan serta menganalisis pengaruh kegiatan kelompok dan pengaruhnya. Tema-tema esensial dalam materi Sosiologi dipilih dan bersumber serta merupakan kajian tentang masyarakat dan perilaku manusia dengan meneliti kelompok yang dibangunnya. Kelompok tersebut mencakup keluarga, suku bangsa, komunitas dan pemerintahan, dan berbagai organisasi sosial, agama, politik, bisnis dan organisasi lainnya.

Materi Sosiologi dikembangkan sebagai suatu lembaga pengetahuan ilmiah dengan teori yang didasarkan pada observasi ilmiah, bukan lagi pada spekulasi dibelakang meja atau observasi impresionistis, (Badan Standar Nasional Pendidikan, 2006). Materi-materi sosiologi khususnya yang ada di kelas $\mathrm{X}$, sangat syarat akan adanya nilainilai karakter. Berdasarakan hasil penelitian menyatakan bahwa nilai-nilai karakter yang dilaksanakan oleh guru mata pelajaran Sosiologi adalah religius, rasa ingin tahu, jujur, disiplin, tangguh, santun, komunikatif, toleransi, demokratis, peduli sosial, tanggung jawab, nasionalisme. Nilai-nilai itulah yang tersirat atau yang menjadi salah tujuan yang harus tersampaikan pada pendidikan karakter melalui salah satunya materi Sosiologi.

Analisis materi kelas $\mathrm{X}$ yang diperoleh berdasarkan Standar Kompetensi (SK) dan Kompetensi Dasar (KD) semester satu kelas $\mathrm{X}$ diantaranya: Sosiologi sebagai ilmu tentang masyarakat, Nilai dan Norma Sosial, Interaksi sosial, sedangkan untuk semester dua materi yang diajarkan adalah Sosialisasi dan pembentukan kepribadian, Perilaku menyimpang dan Pengendalian sosial.

Berikut salah satu analisis materi tiap indikator agar nilai-nilai karakter yang baik dapat tersampaikan salah satunya melalui 
materi Sosiologi kelas $\mathrm{X}$, yaitu bab 1 tentang sosiologi sebagai ilmu tentang Masyarakat. Pada bab 1 materi Sosiologi mengkaji tentang Sosiologi sebagai ilmu masyarakat mengkaji beberapa aspek materi diantaranya: yang pertama, menjelaskan pengertian Sosiologi itu sendiri, objek Sosiologi dan tujuan Sosiologi. Isi dari materi tersebut yaitu bertujuan agar peserta didik memiliki nilai karakter rasa ingin tahu, terhadap apa itu Sosiologi dan objek didalam Sosiologi itu apa saja yang perlu dipelajari. Peserta didik juga selanjutnya dapat memiliki nilai karakter demokratis, komunikatif, santun, toleransi dan peduli sosial setelah mempelajari tujuan dan peran dari Sosiologi itu sendiri yang mengkaji seluruh fenomena dan realita sosial yang ada di masyarakat. Fenomena sosial yang ada di mayarakat baik yang negatif dan positif dapat memberikan gambaran bagaimana peserta didik sebagai individu dan kelompok dapat berperilaku sebagai warga masyarakat yang baik agar tercipta suatu keteraturan sosial.

Aspek kedua untuk pendidikan karakter adalah silabus. Silabus merupakan acuan pembelajaran yang berisi rencana bahan ajar mata pelajaran tertententu, sebagai hasil dari seleksi, pengelompokan, pengurutan, dan penyajian materi kurikulum, yang dipertimbangkan berdasarkan ciri dan kebutuhan daerah setempat. Berdasarkan hasil analisis disimpulkan bahwa pengembangan silabus dalam pengintegrasian nilai-nilai karakter pada perangkat pembelajaran khususnya Silabus oleh guru mata pelajaran Sosiologi yaitu Bapak Drs. Suratno dengan cara menambahkan kolom nilai-nilai karakter setelah kolom materi pada silabus itu sendiri. Nilai-nilai karakter yang diintegrasikan kedalam silabus tersebut masih bersifat umum belum secara spesifik. Artinya nilai-nilai karakter yang ada di dalam silabus masih keseluruhan dari nilai-nilai karakter yang dianalisis berdasarkan karakteristik mata pelajaran Sosiologi, bukan berdasarkan materi bahan ajar.

Jadi kesimpulan pengembangan silabus yang dilakukan oleh Bapak Drs. Suratno selaku guru mata pelajaran secara keseluruhan yaitu: (1) penulisan identitas mata pela- jaran; (2) perumusan standar kompetensi; (3) penentuan kompetensi dasar; (4) penentuan materi pokok dan uraiannya; (5) penentuan nilai-nilai karakter yang diintegrasikan; (6) pengalaman belajar; (7) penentuan alokasi waktu; dan (8) penentuan sumber bahan. Nilai-nilai karakter yang terdapat pada pengembangan silabus yang dibuat oleh Bapak Drs. Suratno di antaranya: religius, rasa ingin tahu, jujur, disiplin, tangguh, santun, komunikatif, toleransi, demokratis, peduli sosial, tanggung jawab, nasionalisme. Nilainilai karakter itulah yang nantinya masih akan dianalisis untuk pengintegrasian nilainilai karakter ke dalam RPP. Secara lebih rinci untuk bentuk silabus berkarakter yang dikembangkan oleh bapak Drs. Suratno dapat dilihat pada lampiran penelitian ini.

Perencanaan pembelajaran yang berupa Rencana Pelaksanaan Pembelajaran (RPP) merupakan rancangan awal kegiatan tahap demi tahap apa yang akan dilakukan guru dengan peserta didik dalam kegiatan pembelajaran untuk setiap kali pertemuan pada suatu pokok bahasan tertentu. Perencanaan tersebut disusun oleh guru agar agar kegiatan pembelajran dapat tertata dengan baik, meskipun pada prakteknya tidak selalu sama persis dengan apa yang sudah di konsep dalam RPP. Hakikatnya apa yang direncanakan dapat dilaksanakan dengan baik agar sesuatu yang akan disampaikan dapat ditransfer dan diterima oleh peserta didik dengan mudah. Sebagai upaya untuk mewujudkan hal tersebut, maka diperlukan suatu persiapan yang matang sebelum melaksanakan kegiatan.

Secara umum dan garis besar pembuatan RPP berkarakter oleh Bapak Drs. Suratno sesuai dengan panduan yang ada, hanya saja ditambah dengan pengintegrasian nilai-nilai karakter setelah poin tujuan pembelajaran. Penjabaran dan penjelasan secara rinci dituliskan pada poin nilai-nilai karakter yang dikembangkan. Pada kegiatan inti atau pembelajaran juga tidak lupa oleh Bapak Drs. Suratno disisipi dengan nilai-nilai karakter yang akan dikembangkan baik pada pendahuluan / pembuka, kegiatan inti terdiri atas, eksplorasi, elaborasi, dan konfirmasi, kegiatan penutup. Pada pemilihan metode 
belajar pun pemilahannya tidak begitu saja menentukan metode yang akan digunakan melainkan disesuaikan dengan materi ajar yang akan disampaikan dan tidak lupa pemilihan metode pembelajaran tersebut juga disisipi dengan nilai-nilai karakter yang akan dikembangkan.

Pada materi ajar di RPP, secara lebih detail juga diintegrasikan nilai-nilai karakter melalui materi pelajaran Sosiologi. Pada materi RPP yang dibuat buat oleh Drs. Suratno juga ditambah dengan nilai-nilai karakter yang ada. Sehingga tidak hanya di silabus dan RPP saja pengintegrasian nilai-nilai karakter yang ada melainkan juga pada bahan ajar atau materi ajar yang akan digunakan.

Nilai-nilai pendidikan karakter berdasarkan dari Permendiknas No. 2 Tahun 2010 terdapat 18 nilai karakter. Berdasarkan atas karakteristik dari mata pelajaran Sosiologi dan analisis dari materi pelajaran Sosiologi itu sendiri nilai-nilai karakter bangsa yang ada seperti bersahabat atau komunikatif, peduli sosial, peduli lingkungan, religius, solidaritas dan toleransi. Nilai karakter ini di peroleh berdasarkan standar kompetensi dan kompetensi dasar yang sudah dianalisis di kelas X yaitu meliputi Standar Kompetensi memahami perilaku keteraturan hidup sesuai dengan nilai-dan norma yang berlaku dalam masyarakat. Berdasarkan Standar Kompetensi tersebut membuat individu untuk dapat menjadi anggota msyarakat yang baik, bapat menghayati nilai-nilai yang ada di masyarakat, mengembangkan jiwa sosial yang tinggi dalam berperilaku sehari-hari sehingga dapat menjadi masayarakat yang berkarakter nantinya.

Berikut beberapa metode yang digunakan Bapak Drs. Suratno selaku guru mata pelajaran Sosiologi dalam melakukan penanaman nilai-nilai pendidikan karakter baik didalam kelas maupun di luar kelas, diantaranya: ceramah, keteladanan, penanaman kedisiplinan dan pembiasaan.

Proses penanaman nilai-nilai karakter juga dapat diberikan melalui metode ceramah. Ceramah dapat diberikan dengan menggunakan contoh kasus ataupun nasehat-nasehat yang diberikan ketika peserta didik melakukan suatu kesalahan. Pemilihan metode ceramah ini didasarkan pada pemikiran bahwa peserta didik lebih menyerap hukuman yang berupa nasehat-nasehat oleh guru daripada hukuman-hukuman yang sifatnya mental dan fisik.

Keteladanan memiliki kontribusi yang sangat besar dalam mendidik karkter. Keteladanan guru dalam berbagai aktivitasnya akan menjadi cerminan peserta didiknya. Sosok guru yang bisa diteladani peserta didik sangat penting. Guru dapat menjadi tokoh idola dan panutan bagi anak. Oleh karena itu, dituntut ketulusan, keteguhan dan konsisten sikap dari seorang guru.

Kedisiplinan menjadi alat yang ampuh dalam mendidik karakter. Banyak orang sukses karena menegakkan kedisiplinan. Sebaliknya, banyak upaya membangun sesuatu tidak berhasil karena kurang atau tidak disiplin. Menanamkan prinsip agar peserta didik memiliki pendirian yang kokoh merupakan bagian yang sangat penting dari strategi menegakkan kedisiplinan. Kedisiplinan yang diterapkan atau dilaksanakan oleh guru Sosiologi yaitu Bapak Drs. Suratno cukup ketat, dalam arti Bapak Drs. Suratno menegakkan kedisiplinan dalam berbagai aspek. Mulai dari awal pembelajaran hingga akhir pembelajaran.

Pendidikan karakter tidak cukup hanya diajarkan melalui mata pelajaran di kelas, tetapi juga harus diterapkan melalui suatu pembiasaan. Kegiatan pembiasaan secara spontan dapat dilakukan misalnya saling menyapa, baik antar teman, antar guru maupun antar guru dan peserta didik. Pembiasaan diarahkan pada upaya pembudayaan pada aktivitas tertentu sehingga menjadi aktivitas yang terpola atau tersistem.

Penciptaan suasana kondusif di dalam kelas merupakan hal utama yang harus diciptakan terlebih dahulu guna ingin mencapai tujuan pembelajaran yang akan menjadi target nantinya. Suasana yang gaduh, tidak tenang, banyak masalah antar peserta didik akan menjadi hambatan dalam proses belajar mengajar baik guru mentansfer ilmu atau mendidik peserta didik itu sendiri. sehingga diperlukan sekali penciptaan suasana yang kondusif dalam mendukung atau agar penyampaian nilai-nilai karakter yang menjadi 
tujuan dapat tersampaikan dengan baik dan tepat sasaran.

Aspek berikutnya dalam pendidikan karakter adalah media pembelajaran. Media yang digunakan oleh guru mata pelajaran Sosiologi ada di antaranya seperti hal yang sudah dipaparkan di atas yaitu media yang digunakan oleh Bapak Drs. Suratno dalam menunjang proses pembelajaran Sosiologi dan penanaman nilai-nilai pendidikan karakter, diantaranya: Gambar dan Foto, Film, Televisi, VCD (Compact Video Disc), LCD. Pembelajaran di SMA Negeri 5 Semarang juga ditunjang dengan adanya PSB (Pusat Sumber Belajar). PSB ini mempunyai beberapa manfaat yaitu sebagai media informasi yang berkaitan dengan pendidikan dan komunikasi antar pendidik, pendidik dengan peserta didik, maupun antar satuan pendidikan.

Berdasarkan uraian di atas dapat disimpulkan bahwa nilai dan manfaat media pembelajaran dalam mempertinggi proses belajar peserta didik karena: 1) pengajaran akan lebih menarik perhatian peserta didik sehingga dapat menumbuhkan motivasi belajar menumbuhkan nilai karakter rasa ingin tahu; 2) bahan pengajaran akan lebih jelas maknanya sehingga dapat lebih dipahami oleh para peserta didik dan memungkinkan peserta didik menguasai tujuan pengajaran yang lebih baik sehingga dapat menumbuhkan nilai karaker rasa ingin tahu atau cerdas; 3) metode mengajar akan lebih bervariasi sehingga merangsang anak untuk dapat lebih kreatif dalam berbagai hal; dan 4) peserta didik lebih banyak melakukan kegiatan belajar menumbuhkan nilai karakter aktif, berfikir kritis dan lain-lain.

Aspek berikutnya adalah evaluasi. Penilaian pendidikan karakter dititikberatkan kepada keberhasilan penerapan nilai-nilai dalam sikap dan perilaku peserta didik sesuai dengan nilai-nilai karakter yang diterapkan dan diamalkan dalam kehidupan sehari-hari. Jenis penilaian dapat berbentuk penilaian sikap dan perilaku, baik individu maupun kelompok. Sampai saat ini untuk panduan penilaian pendidikan secara umum belum ada, dari pusat kurikulum pun belum ada seperti apa format evaluasi atau penilaian yang da- pat digunakan. Tidak adanya panduan yang jelas tidak membuat pihak SMA Negeri 5 tidak melakukan evaluasi. Format penilaian pendidikan karakter yang dibuat oleh pihak SMA Negeri 5 Semarang berdasarkan rapat bersama ada dua format penilaian yang dapat digunakan oleh guru dalam menilai perilaku peserta didik.

Cara penilaian atau evaluasi pendidikan karakter di SMA Negeri 5 Semarang dilakukan oleh semua guru. Hasil penilaian diinformasikan secara terkoordinasi kepada guru, wali kelas, guru Bimbingan Konseling dan Kepala Sekolah. Penilaian dilaksanakan setiap saat, baik pada jam perlajaran dan pada setiap tempat baik di kelas maupun di luar kelas, dengan cara pengamatan dan pencatatan.

Hasil penilaian pendidikan karakter ditunjukkan untuk mendapatkan gambaran yang menyeluruh tentang nilai-nilai karakter yang telah ditanamkan kepada peserta didik yang tercermin dalam kualitas hidup seharihari, bukan nilai-nilai berbentuk kuantitatif. Informasi yang diperoleh melalui hasil penilaian dapat memberikan gambaran perilaku peserta didik secara individual. Semua informasi ini digunakan hanya untuk perbaikan tingkah laku peserta didik (diagnostik). Hasil penilaian tersebut diharapkan perilaku yang mencerminkan karakter peserta didik senantiasa dapat diketahui dan diperbaiki. Informasi yang diperoleh dari berbagai teknik penilaian kemudian dianalisis oleh guru untuk memperoleh gambaran tentang pendidikan karakrter yang telah dilaksanakan. Gambaran menyeluruh tersebut dilaporkan sebagai suplemen buku rapor oleh wali kelas.

Bagaimana dengan pengimplementasian nilai-nilai pendidikan karakter oleh peserta didik Kelas X dalam kehidupan sehari-hari? Bentuk implementasi beberapa nilai-nilai tersebutlah juga terlihat pada peserta didik SMA Negeri 5 Semarang dalam menerapkan atau mengimplementasikan nilai-nilai karakter yaitu: nasionalisme, peduli sosial, religius, toleransi, disiplin, demokratis, rasa ingin tahu, jujur, santun, tangguh, dan tanggungjawab, yang diperolehnya dari mempelajari Sosiologi.

Religius diajarkan dengan berdo'a 
sebelum dan sesudah pelajaran, Ikut aktif dalam kegiatan kerohanian atau siraman rohani, Taat dan rajin beribadah, Shalat berjama'ah bersama di sekolah. Jujur dengan jujur dalam menggunakan uang saku, jujur mengerjakan tugas dan ulangan, Jujur mengembalikan barang milik orang lain, Selalu meminta maaf jika salah kepada orang lain, jujur dalam pertandingan olahraga.

Disiplin diekspresikan dengan disiplin pulang ke rumah tepat waktu, Disiplin membayarkan uang sekolah, Disiplin mentaati peraturan sekolah, Disiplin dalam mengumpulkan tugas sekolah, Disiplin antri di kantin, toilet dan koperasi. Santun diekspresikan dengan santun dalam berbicara dengan orang tua dan guru, Santun dalam berjalan di depan orang tua dan guru, Santun ketika berangkat ke sekolah, Santun dalam masuk rumah atau kelas. Tangguh diekspresikan dalam ketangguhan dalam menolong orang yang sakit (PMR), Tangguh dalam melindungi diri sendiri (Perisai), Tangguh dalam menjaga alam (Pecinta Alam).

Toleransi dengan menghargai teman yang sedang beribadah, Menghargai pendapat orang lain. Demokratis dengan berpartisi pasi dalam pemilihan ketua OSIS, Berpartisipasi dalam pemilihan ketua kelas, Pemilihan ketua Karang Taruna di desa. Nasionalisme dengan Mengikuti upacara rutin setiap Senin, Menjaga foto para pahlawan di kelas, Mendengarkan lagu perjuangan. Peduli sosial dan solidaritas dilaksanakan dengan bakti sosial, menjenguk dan membantu teman yang sakit, mengunjungi keluarga teman yang terkena musibah, Membantu orang tua yang akan menyebrang jalan. Tanggung jawab dilaksanakan dalam membayar kas kelas, Tanggung jawab dalam kebersihan piket kelas, Tanggung jawab dalam mengerjakan tugas kelompok, Tanggung jawab dalam pekerjaan rumah.

\section{SIMPULAN}

Hasil penelitian menunjukkan bahwa: (1) Pendidikan karakter di SMA Negeri 5 Semarang dilaksanakan bukan menjadi mata pelajaran yang berdiri sendiri melainkan diintegrasikan ke semua mata pelajaran yang ada. (2) Proses penanaman nilai-nilai pendidikan karakter melalui mata pelajaran salah satunya dapat diketahui melalui penanaman nilai-nilai pendidikan karakter pada mata pelajaran Sosiologi kelas X. (3) Penanaman nilai-nilai pendidikan karakter melalui mata pelajaran Sosiologi dapat ditinjua dari beberapa aspek, di antaranya: materi Sosiologi yang telah dianalisis nilai-nilai karakternya, RPP dan Silabus Sosiologi yang berkarakter, metode penanaman oleh guru, media pembelajaran berbasis karakter dan evaluasi penanaman nilai-nilai pendidikan karakter. (4) Pengembangan dan penanaman nilai-nilai pendidikan karakter di SMA Negeri 5 Semarang selain melalui pengintegrasian disetiap mata pelajaran juga melalui penyediaan fasilitas yang ada seperti tempat ibadah, laboratorium bahasa dan budaya serta Pusat Sumber Belajar yang baik serta ditunjang dengan berbagai program sekolah mulai dari ekstra kurikuler, pengembangan budaya sekolah, wawasan wiyata mandala dan tentunya ditunjang dengan Visi dan Misi sekolah yang ada. Nilai-nilai pendidikan karakter yang ada di SMA Negeri 5 Semarang berdasarkan atas Permendiknas No. 2 tahun 2011 yang memuat 18 indikator nilai-nilai karakter bangasa tetapi sesuai dengan karakteristik mata pelajaran Sosiologi sendiri nilai karakter yang ada seperti: bersahabat atau komunikatif, peduli sosial, peduli lingkungan, religius, solidaritas dan toleransi. Nilai-nilai karakter bersahabat atau komunikatif, peduli sosial, peduli lingkungan, religius, solidaritas dan toleransi, berdasarkan analisis mata pelajaran Sosiologi, nilai tersebut mempunyai ranah dimensi sosial sesuai dengan prinsip pendidikan karakter yaitu nilai-nilai karakter yang ada tidak hanya nilai berdimensi individual tetapi juga ranah sosial.

Saran yang dapat dikemukakan penulis antara lain: Pertama, Pembelajaran di SMA Negeri 5 Semarang tidak hanya menekankan pada aspek-aspek kognitif atau akademik saja (kognitif), melainkan juga harus menekankan pada soft skill atau non-akademik (afektif dan psikomotorik) yang merupakan unsur utama pendidikan karakter. Kedua, Masih ditemukannya beberapa perilaku peserta didik yang kurang berkarakter maka para pendidik 
dan orang tua lebih aktif lagi dalam memberikan pendidikan karakter dengan berbagai metode yang bisa digunakan agar peserta didik semakin lebih baik dan mempunyai karakter yang kuat. Ketiga, Bagi guru-guru di SMA Negeri 5 Semarang, dapat berperan aktif dalam pelaksanaan pembelajaran berbasis karakter dengan mengimplementasikan nilai-nilai pendidikan berkarakter ke dalam perangkat pembelajaran seperti silabus, RPP, serta metode, media dan teknik evaluasi yang digunakan dalam kegiatan belajar mengajar dengan lebik baik lagi. Keempat, Bagi kepala sekolah, dapat mengoptimalkan fungsi tata tertib sekolah dan kegiatan ekstrakurikuler serta selalu menambah program-program pengembangan karakter peserta didik agar penanaman nilai-nilai karakter kepada peserta didik ketika berada di luar kelas dapat dilakukan lebih intensif. Kelima, Fasilitas sekolah yang dapat menunjang pengembangan pendidikan karakter lebih dioptimalkan dan di lingkungan sekolah juga diperbanyak dengan simbol-simbol dan kata-kata mutiara yang diletakkan di tempat yang setrategis agar dapat menumbuhkan karakter peserta didik. Keenam, Kepada dinas pendidikan setempat segera melakukan pelatihan pendidikan karakter bagi para guru, kepala sekolah, pengawas sekolah. Ketujuh, Perlu adanya sosialisasi kepada pihak sekolah terkait dengan hasil penelitian ini agar dapat memberikan masukan terkait dengan pelaksanaan pendidikan karakter di SMA Negeri 5 Semarang.

\section{DAFTAR PUSTAKA}

Akrab, S. 2010. 'Model Pembelajaran Nilai dan Karakter Berbasis Nilai-nilai Kehidupan di Sekolah Dasar: UM Press di Malang'. Dalam Jurnal Ilmu Pendidikan. 1: 46-54

Albertus, D.K. 2010. Pendidikan Karakter Strategi Mendidik Anak Di Zaman Global. Jakarta: PT Grasindo
Badan Standar Nasional Pendidikan. 2006. Petunjuk Teknis Pengembangan Silabus dan Contoh atau Model Silabus SMA/MA. Jakarta: Departemen Pendidikan Nasional

Chrisiana, W. 2005. Upaya Penerapan Pendidikan Karakter Bagi Mahasiswa (Studi Kasus Di Jurusan Teknik Industri UK Petra). Jurnal Teknik Industri. 7(1): 83-90

Fudyartanta, K. 2010. Membangun Kepribadian dan Watak Bangsa Indonesia yang Harmonis dan Intergal. Yogyakarta: Pustaka Belajar

Handoyo, E. dan Tijan. 2010. Model Pendidikan Karakter Berbasis Konservasi, Pengalaman Universitas Negeri Semarang. Semarang: UNNES dan Cipta Prima Nusantara

Insriani, H. 2011. Pembelajaran Sosiologi Yang Menggugah Minat Siswa. Jurnal Komunitas. 3(1): $108-125$

Judiani, S. 2010. Implementasi Pendidikan Karakter Di Sekolah Dasar Melalui Penguatan Pelaksanaan Kurikulum. Jurnal Pendidikan dan Kebudayaan. $16(3)$

Peraturan Menteri Pendidikan Nasional Republik Indonesia Nomor 19 Tahun 2005 Tentang Penetapan Angka Kredit Jabatan Fungsional Pengawas Sekolah. 2005. Jakarta: Diperbanyak oleh Biro Hukum dan Organisasi

Peraturan Menteri Pendidikan Nasional Republik Indonesia Nomor 22 Tahun 2006 Tentang Standar Isi Untuk Satuan Pendidikan Dasar dan Menengah. 2006. Jakarta: Diperbanyak oleh Biro Hukum dan Organisasi

Peraturan Menteri Pendidikan Nasional Republik Indonesia Nomor 23 Tahun 2006 Tentang Standar Kompetensi Lulusan Untuk Satuan Pendidikan Dasar dan Menengah. 2006. Jakarta: Diperbanyak oleh Biro Hukum dan Organisasi

Peraturan Menteri Pendidikan Nasional Republik Indonesia Nomor 41 Tahun 2007 Tentang Standar Proses Untuk Satuan Pendidikan Dasar dan Menengah. 2006. Jakarta: Diperbanyak oleh Biro Hukum dan Organisasi

Raharjo, S.B. 2010. Pendidikan Karakter Sebagai Upaya Menciptakan Akhlak Mulia: Balitbang Kemdiknas di Jakarta. Dalam Jurnal Pendidikan dan Kebudayaan. 3: 229-238

Undang-Undang Republik Indonesia Nomor 20 Tahun 2003 Tentang Sistem Pendidikan Nasional. 2003. Jakarta: Diperbanyak oleh Biro Hukum dan Organisasi 